\title{
Museums and Heritage Sites - The Missing Link in Smart City Planning: A Case Study of Pune City, India
}

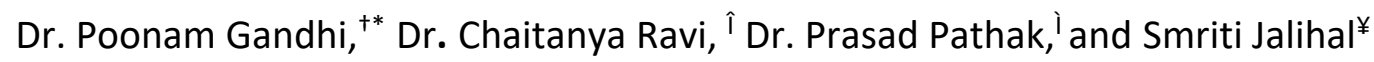

\section{Abstract}

The process of urbanisation has dramatically increased in India in recent years. The Government of India launched Smart City Mission in 2015 which was intended to transform 100 cities into smart cities. The focus of our research is one such city in India on its path to smartification. Pune's smart city mission focuses on techno-infrastructural development to increase mobility and digital connectivity. Social-cultural and historical indicators are not considered an integral part of this development. Given this, does the smart city mission of Pune privilege the techno-infrastructural development of a city over its social and cultural development? In this paper, we identify museums and heritage sites in Pune as signifiers of a city's culture and analyse metro development plans through GIS to understand whether the museums' current geography mentioned above and heritage sites require alignment with Pune's planned smart city mission. The research shows that the quest to 'upgrade' and 'modernise' is not adequately aligned with the role of key historiccultural institutions such as museums and heritage sites. The case of Pune city shows that, without careful and inclusive development plan, a full roll-out of the smart city project will exclude a large number of historical and cultural spaces such as museums and heritage sites from emerging as an integral part of smart cities across the country and render them peripheral to modern urban life.

Keywords: Smart City; Cultural Heritage; GIS; Museums; Urban Development; Pune; India

\footnotetext{
${ }^{\dagger}$ Associate Professor of Sociology, FLAME University, Pune, Maharashtra, India ${ }^{*}$ Corresponding Author, Email: poonam.gandhi@flame.edu.in

${ }^{i}$ Assistant Professor, Public Policy, FLAME University, Pune, Maharashtra, India, Email: chaitanya.ravi@flame.edu.in 'Associate Professor, Environmental Studies, FLAME Centre for Earth and Environment, FLAME University, Pune, Maharashtra, India, Email: prasad.pathak@flame.edu.in

${ }^{¥}$ Research Assistant, Environmental Studies and Public Policy, FLAME University, Pune, Maharashtra, India, Email: smriti.jalihal@flame.edu.in

(C) 2021 Gandhi et al. This is an Open Access article distributed under the terms of the Creative Commons Attribution License (http://creativecommons.org/licenses/by/2.0), which permits unrestricted use, distribution, and reproduction in any medium, provided the original work is properly cited.
} 


\section{Introduction}

India's rapid economic growth of recent years has dramatically increased rates of urbanisation. The population in urban areas has risen from 28.3\% to $31.16 \%$ from 2001 to 2011 (Census of India, 2011). The World Bank estimates that India's urban population increased further to 34\% as of 2018 (The World Bank, 2018). The Government of India in 2015 launched Smart City Mission which was intended to transform 100 cities (Smart Cities Mission, Government of India, 2016). The key aim of the mission is to "drive economic growth and improve the quality of life of people by enabling local development and harnessing technology as a means to create smart outcomes for citizens" (Smart City Proposal, 2019). The goal was to upgrade Indian cities through techno-infrastructural projects to enhance the quality of life, plug infrastructural deficiencies (Anand et al., 2018), sustain economic growth, and prepare them for further migration from the countryside.

The number of cities competing in the Mission shot up from the previous 98 in 2015 to 110 in 2017 and 99 cities were selected in 5 rounds of selection as the government allowed more state capitals to enter the competition (Anand et al., 2018). The central government would allocate INR 5 Billion to each city over a period of 5 years, and a matching allocation was expected from the state government or the local urban body (ULB) (Anand et al., 2018). The selected cities went through a public consultation and came up with different project plans which each city was to implement to become "smart". Currently, the selected cities are each in various stages of development, and the totality of such projects will have significant implications for the trajectory of Indian urbanisation. Several studies have examined smart cities' definitions, one such study reflected on twenty-three definitions of the term smart city. According to Hall and colleagues (2000), the central tenet of a smart city was the use of ICT to monitor and integrate public infrastructure. Whereas, Caragliu et al. (2011) focused on clever solutions allowing modern cities to thrive, through quantitative and qualitative improvements in productivity. Townsend (2013) defines smart cities as places where information technology is combined with infrastructure, architecture, everyday objects, and our own bodies to address social, economic, and environmental problems. The authors highlight the shift in the definition of a smart city away from one solely focused on technology and toward a definition that often encompasses people, the community, and the environment (Smith, Pathak, \& Agrawal, 2019). Given that there are several indicators of 'smartness', does culture and heritage feature in the process of developing a smart city?

The smart city mission portal of Government of India mentions that there is no clear global definition of "Smart City". For India, however, the following broad definition has been accepted:

In the approach of the Smart Cities Mission, the objective is to promote cities that provide core infrastructure and give a decent quality of life to its citizens, a clean and sustainable environment and application of 'Smart' Solutions. The focus is on sustainable and inclusive development and the idea is to look at compact areas, create a replicable model which will act like a light house to other aspiring cities (smartcities.gov.in, 2019).

This paper focuses on Pune, a city in western India with a population of 3.12 Million (Census of India, 2011) and a GDP of $\$ 48$ billion which secured its place in the Smart Cities Mission in the very first round of selection, ranking second in the nation in 2015 (Pune Smart City Pune, 2019). Pune's smart mission focuses on technoinfrastructural development to increase mobility and digital connectivity. Some of the 'upgrades' and 'retrofits' promised are free Wi-Fi zones, smart street redesign, smart placemaking, street lighting, CCTV cameras and crowdsourcing of solutions (Pune Smart City Pune, 2019). The overall approach of the Pune smart city plan is one predicated on technological determinism where the hard infrastructure such as roads, 
bridges and metros and soft infrastructure such as increased Wi-Fi connectivity provided by IT are assumed to be sufficient, to upgrade a city.

A fundamental limitation of this approach is its assumption that cities can be built or upgraded using those mentioned above hard-soft infrastructural combination alone, creating the enabling conditions for rapid growth in urban population, economic growth and quality of life. But cities do not just have physical geography that technology can bring together through hard and soft networks and a cultural geography. This cultural geography, consisting of vital historypreserving and identity-building institutions such as museums should be equally important for the cohesiveness and quality of life in a city. The smart city mission lists 24 criteria out of which culture and identity are listed criteria, and this leads us to question how are these reflected in the city development plans? (Smart City Proposal, 2019).

The Pune Smart City Mission's aim, driven through techno-economic development raises the question as to whether India's development has historically been delinked with social and cultural growth and if development refers only to technological and economic advancement? Moreover, whether such development is sustainable and ensures a high quality of urban life. Development, planning and change, sociologically speaking, are interrelated and interlinked. Development refers to social change which is planned and desired by society. However, technological determinism is considered an important feature of development. It is a theory that emphasises the influence of technology on societal development and highlights its influence on the social, cultural and organisational structures of society (Dafoe, 2015). Given this understanding, this research's key questions are- does the smart city mission privilege the techno-infrastructural development of a city over its social and cultural development? Are the development plans of Pune city holistic and inclusive in nature, or are they atomistic in nature? What does the current geography of Pune's museums', and metro route tell us about its smart city development plans?
Through this paper, an attempt is made to seek answers to these questions. The literature review and analysis of the current smart city plans helps identify the lacunae in incorporating the heritage ecosystem into Pune smart city plans. By demonstrating through maps, metro lines, and heritage sites, the researchers highlight how the city of Pune's core identity is missing from the overall smart city development plans. Thus, Pune city's case with its growing IT hub illustrates the missing link of including the rich cultural heritage of Pune in smart city planning. The proposed strategy is to have a more holistic, inclusive and context-specific smart city planning that reflects the city's cultural geography.

Table 1 depicts the paradigm shift proposed through this study, highlighting the need to incorporate heritage ecosystems and align it with the existing economic ecosystem for a holistic smart city development plan.

\section{Methodology}

This paper examines museums' location, tourist sites-monuments and metro routes in the current geography of Pune city to examine if the smart city mission has incorporated the cultural development of the city in its planning, as evidenced through the inclusion of museums and monuments in crucial transportation projects. Through GIS mapping and content analysis of secondary sources, an attempt is made to scrutinise the development plans of Pune city and to examine if museums and heritage sites have been incorporated in them. The museums and monuments of Pune, in particular, have been focused along with the city tourism routes and interconnection is hypothesised which serves to explain the smart city plan and the peripheral location of museums in the development plans. Considering museums and heritage sites as the important signifiers of culture, an attempt is made to identify their locations and examine the metro routes which are essential transportation connectors to these museums' sites and historical monuments. The convergence or lack of it along the metro routes with museums is considered an indicative measure for the inclusivity or lack thereof of the 
city's smart city plans. This method allows the researchers to verify the hypothesis and propose a paradigm of holistic city development plans.

Spatial data of Pune was collected from open source datameet portal and was verified using PMCs Open Data Portal (Datameet, Github, 2019). It included metro routes and Pune ward map with the ward names. The delineation of ABD (Area Based Development) was carried out using Google Earth images. The museums/heritage sites were geolocated using a survey with GPS. The coordinates were then transferred into GIS. All the data is projected in UTM zone 43 projections. Within the heritage site survey, detailed attributes about each site were collected. This data was used to depict sites included in Pune sightseeing locations and museums. QGIS 3.10 software was used to carry out the superimposing of the wards, metro routes and the heritage sites (Datameet, Github, 2019). The existing literature is reviewed in the following section to delineate the gap in literature.

\begin{tabular}{|c|c|c|}
\hline Criteria & Current Smart City Paradigm & Proposed paradigm \\
\hline Foundational assumption & $\begin{array}{l}\text { Techno-infrastructural } \\
\text { projects }\end{array}$ & $\begin{array}{l}\text { Techno-infrastructural } \\
\text { projects aligned with socio- } \\
\text { cultural sites }\end{array}$ \\
\hline Operationalisation & $\begin{array}{l}\text { Area-based and pan-city } \\
\text { projects }\end{array}$ & $\begin{array}{l}\text { Stand-alone museums and } \\
\text { monuments, increasingly } \\
\text { connected by current smart } \\
\text { city projects }\end{array}$ \\
\hline Goals & $\begin{array}{l}\text { 1) Ease of mobility } \\
\text { 2) Economic growth } \\
\text { 3) Higher quality of } \\
\text { material life }\end{array}$ & $\begin{array}{l}\text { 1) Ease of mobility } \\
\text { 2) Ease of access to } \\
\text { heritage sites } \\
\text { 3) Higher quality of } \\
\text { overall life (material } \\
\text { life, popular culture } \\
\text { and heritage- } \\
\text { influenced high } \\
\text { culture) }\end{array}$ \\
\hline Broader aim & 1) Economic ecosystem & $\begin{array}{l}\text { 2) Interconnected } \\
\text { heritage ecosystem in } \\
\text { alignment with the } \\
\text { economic ecosystem }\end{array}$ \\
\hline
\end{tabular}

\section{Literature Review}

The literature on development, urbanisation and smart cities has covered an array of questions and provided fuel for further research. For the currently proposed research, studies covering cultural identity, smart city, and urbanisation are reviewed. Review of the core question, 'what is a smart city?' brings to fore the limitations of the global understanding of the concept. Many countries have evolving smart cities. The key features of these smart cities differ based on their priority, and hence, there is no unique definition. According to the government of India, social, economic, physical and institutional development should be the pillars for smart cities in India (What is Smart City? Government of India). Overall, a sustainable and inclusive growth, in line with the UN's Sustainable Development Goals, is being envisioned in the Smart City Mission, India. However, the 100 smart cities in the mission focus on using ICT, urban management, and things like ease of doing business to ensure rapid urban development. They thoroughly lack citizen engagement via ICT as well as do not capture cities' cultural identities to provide unique 
solutions to individual cities (Han \& Hawken, 2018). Allam and Newman (2018) also suggested that one-size-fits-all solutions cannot work for cities by just calling them smart. Individual cities have to consider their own history and heritage alongside urban development planning. Otherwise, the very reason why cities grew in the first place would be degenerated.

Seemingly, Pune has an interesting history and cultural significance, making it an engaging case study of smart city mission. Diddee, Gupta and Bhandare (2000) explained that Pune's growth can be classified into three distinct time periods. Pune city's growth has been researched extensively from the cultural-historical context. Diddee, Gupta and Bhandare (2000) explained that Pune's growth can be classified into three distinct time periods. The one before British raj, that is, before 1818; during the British period (1818 to 1947) and post-independence. Museums in Pune represent and have conserved history and heritage from the first two periods. The city has other heritage sites which are mostly temples, forts, and other places of significance. The post-independence growth of the city has happened at the cost of development of agriculture land around the urban boundaries and has not paid attention to explore any early or modern heritage in those peri-urban areas (Mundhe \& Jaybhaye, 2017).

In a recent study, Ziyaee (2018) claims that rapid urbanisation through modern physical structures has created gaps in cities' cultural identity. While studying Mashhad city through a matrix of the cultural landscape, the author suggested that cultural landscapes' tangible and intangible characteristics should be critical for new urban developments. Vogeler (2010) mentioned cultural meaning and message (ideas, beliefs), human activities, physical forms (topography, vegetation, structure) as components of the matrix of the cultural landscape. It is of significance to examine Pune smart city planners' approach and assess if cultural heritage is incorporated in the planning.

\footnotetext{
${ }^{1}$ Postcolonial theory deals with the effects of colonization on cultures and societies and those societies' responses to
}

Our study aims to examine this in the context of Pune's 'smartification' process.

Separating living cultural heritage from the people's daily lives may not reflect the city's identity in its most accurate form. Sonkoly (2017) divided the cultural landscape into living cultural heritage and built cultural heritage. Each of these two categories were further subdivided into the tangible and intangible ones. For example, religious or cultural use of urban space was categorised as a tangible indicator and household items used in a particular place was also considered a tangible indicator within living cultural heritages. Cultural activities themselves were considered as intangibles indicators within living cultural heritage. Sonkoly (2017) classified monuments as tangible built cultural heritages while a sense of a place, land use pattern, and expression (architecture) as intangible built cultural heritage. With Pune city being considered having culturally rich heritage examining the tangible and intangible elements is culturally rich heritage examining the tangible and intangible elements is crucial to its transformation into a smart modern city. This research intends to gain a deeper understanding of these elements with regards to Pune. Datta's (2015) study of Dholera, India's first smart city in Gujarat, revealed how, Dholera's ethos of "entrepreneurial urbanisation" was built into it by a Gujarat government determined to make it a demonstration city for the rest of the country for the virtues of the Gujarat model of development. This ethos (Gujarat model which emphasised speed, efficiency and connectivity) has resulted in an emphasis on speed and efficiency akin to the West, which ultimately runs into bottlenecks when it confronts the city's variegated cultural geography. The essence of cultural space lies in understanding the communities, people and their socio-cultural environ. The current paper is a step towards studying these interlinkages between people, communities, culture and development.

Datta (2018) has interestingly discussed postcolonial urban theory ${ }^{1}$ dealing with the idea

it (Ashcroft, 2017). It is not a singular concept and encompasses a range of scholarship in urban studies that 
of the Smart Cities Programme in India which emphasises the use of digital technologies to transform Indian cities. The concept of the smart city extends well beyond mere connectivity and now includes "big data, algorithmic governance and automated urban management." (pp. 406). Thus, the concept of a smart city represents a technocratic form of governance (pp. 407). And an interesting form of urbanism that smart city concept promotes consists of Middle class "islands" are connected by the smart city through a "splintered urbanism²." (pp. 407). The concept of smart city is a data-hungry one. Using numerous data points, it can find and record populations that would be left out by other conventional surveys such as the Indian government's census. "The smart city concept is too English/foreign and needs to be vernacularized and nativized to create contextspecific Chathur cities and Chathur citizens in India" (Datta, 2018 pp. 409). This paper highlights the urgent need to Indianise the concept of smart cities. The review undertaken reflects the need to understand and focus on a city's cultural heritage to nativise the smart city missions.

\section{Museums as Vital Expressions of Culture and Heritage}

Museums play a crucial role in preserving the cultures of the world. Museums for most of the 21st Century contributed as centres of archaeology and art history, where art and artefacts were researched and displayed for public enjoyment. In the last few decades museums have become places where memories of different communities are stored and celebrated. Museums document daily lives of people and communities that facilitate preservation, especially when cultures and cultural elements are fast disappearing. Careful preservation is one of the most significant ways to protect and safeguard the heritage of the world.

engages with postcolonial theory, post coloniality as a historico-politico status, and postcolonial criticism of urban theory.

${ }^{2}$ A term coined by geographers Steven Graham and Simon Marvin to refer to the ways in which infrastructures,
Museums also play an essential role in educating and transmitting knowledge. In the globalised world of high-tech gadgets, it is crucial to educate people regarding varied cultures, incredibly respectful displays of the past's local/regional cultures. Moreover, museums are delightful places to ensure that visitors engage visually with the preserved cultures. Pune has more than 30 museums, and apart from the Raja Dinkar Kelkar Museum and War Memorial Museum, there are private collections and dedicated museums like the Numismatics Museum, the Cycle Museum, the Camera Museum and the Vintage Car Museum, to name a few. Pune city has 13 state-owned museums out of 30, whereas individual collectors own 10, 8 by trusts and institutes and one is owned and run by the defence establishment.

\section{Museums and Monuments, High-Culture and the Cultural Void}

Cities such as DC, Paris and London do not just offer the tangible benefits of lucrative jobs but also the intangible and equally important benefits of infotainment and positive identity formation through institutions such as museums. A good example of the embedding of museums into city planning with implications for urban culture is Washington DC. The Smithsonian Metro Station opened in 1977 is accessible by the Washington Metropolitan Area Transit Authority's (WMATA) orange, blue and silver lines good frequency of trains. Several museums such as the Smithsonian National Museum of Natural History, National Museum of American History and the popular Air and Space Museum are within easy walking distance (Smithsonian Institute, 2019). The result of such easy access is a constant stream of DC residents, visitors from around the country and foreign tourists who can avoid the city's vehicular traffic and easily access its museums via mass transit. The Air and Space Museum was the second most visited museum in the world, with 7.5 million

including information and communication technologies, can fragment the experience of the city (Williams, Robles, Dourish 2009). 
visitors in 2016 (Katz, 2017). The museums and proactive urban planning enabling easy-access to them have not just spread a culture of learning and mutual respect among visitors but also been converted into revenues via the food and memorabilia purchases. This coupled with the overall ecosystem of good restaurants, parks, and culture venues, all connected by mass transit, helps $D C$ remain interesting to its highly educated workforce employed in government, as government contractors, and in supporting industries (Financial Times, 2020). As a capital city, DC's status accords it more importance in terms of urban planning in the American system than Pune as a still-emerging city does in India. Despite this crucial difference, Pune's smart city planners can imbibe the insight of at least considering museums and allied cultural institutions as a factor in their smart city buildup, which is not happening presently.

Similarly, the Louvre Rivoli Paris Metro stop is a 2 min walk away from the iconic Louvre Museum, which recorded 10.2 million visitors in 2018 with foreigners accounting for $75 \%$ of the footfall (BBC, 2019). The museum has played an important role in helping the city recover from terror attacks and regain its status as one of the world's premier tourist destinations (BBC, 2019). Clearly, the Louvre and other French museums are better funded and maintained than Pune's museums. However, the current poorly maintained state of Pune's museums should not be considered the sole criterion for their marginalisation from smart city plans for this will condemn them to be peripheral institutions in perpetuity, away from the core transportation nodes that move traffic away from them. Smart city planners in Pune too need to view museums not just as peripheral institutions but as potential creators of a heritage economy with easy-access and other enhancements such as smart pavements, free $\mathrm{Wi}-\mathrm{Fi}$ and other basic amenities. London's extensive mass transit network is similarly designed to help its enormous tourist influx to access the city's iconic museums easily.

There is a need to cultivate a culture of preserving the heritage and promote participatory cultural growth along with shared responsibility involving citizens in managing and promoting cultural heritage via more inclusive smart city paradigms. There are three broad reasons why cultivating art and culture is of great importance to smart cities. First, art and culture enhance a city's liveability by offering creative pursuits and entertainment to which citizens can unwind, and be inspired by. Art and culture also offer ways to engage across communities and social networks. Second, it helps to attract, nurture and retain the young urban workforce that the smart city depends on. A city without a thriving art and culture scene is less likely to retain the workforce required in an increasingly digital work environment. Art and culture ecosystems nurture creativity, leading to innovation and creative thinking within technical jobs. Third, art and culture are important for a city's branding as an attractive and happening place to move to or visit. It is not necessarily the case that a tourist-focused art and culture initiative would be successful. Instead, a city with a deep-rooted art and culture scene, is more likely to attract tourists because it is considered a fun and interesting place to be (Sonne, 2018).

Further, art and culture also cultivate respect for diverse histories and cultures by showcasing them. Museums such as the Native American Museum and the African American Museum in Washington DC have played an important role in sensitising the DC community and others across the country to the richness of Native American and Black culture and their respective contributions to the American story. This cultivates mutual respect and helps strengthen the cohesiveness of society. Given the potential of museums and monuments to help organise diverse cities enabling inter-cultural and interethnic learning with implications for communal harmony, smart city planners in India should attempt to align their plans with the museums and monuments in cities. The urban renewal, social networking, mutual learning and peacebuilding implications of this alignment have positive economic implications as being recognised by cities around the world (Yang et al., 2016). 


\section{Museums and Monuments in Pune}

The assumption underlying Pune's current smart city plan and the infrastructure initiatives supposes that the city's transformation into an urban space attractive for original residents and immigrants depends majorly on a technoinfrastructural approach. It is presumed that high penetration of technology such as free Wi$\mathrm{Fi}$ zones, walk-able pathways in select neighbourhoods, street lighting and major infrastructural projects such as the Pune
Metrorail can reshape Pune's physical geography into one that serves as a magnet for citizens, immigrants and industry. Missing from this planning is a deeper understanding of specific institutions' role in producing a distinct urban culture that gives great cities their characteristic 'flavour' and helps them retain productive populations. As stated above, Pune city has several important museums and monuments of historical and cultural significance that have helped foster a unique urban culture (see, Table 2).

\begin{tabular}{|c|c|c|}
\hline Name of the site & Cultural/ Historic significance & $\begin{array}{l}\text { Era/Year in which } \\
\text { it was built }\end{array}$ \\
\hline Pataleshwar Caves & One of Pune's oldest monuments houses a Shiva temple & 8th Century \\
\hline Lal Mahal & $\begin{array}{l}\text { House where Shivaji spent his childhood and it is also where } \\
\text { Shivaji cut Shaista Khan's fingers. Was built by Shahji } \\
\text { Bhosale for Jijabai and his son Shivaji (Pune Municipal } \\
\text { Corporation, 2019) }\end{array}$ & 1630 \\
\hline Shaniwar Wada & $\begin{array}{l}\text { One of the most important landmarks in the city and one of } \\
\text { the defining monuments of the Peshwas, it was a seat of the } \\
\text { Peshwa Rule until } 1818 \text { and later a centre of Indian Politics } \\
\text { during the British rule }\end{array}$ & 1732 \\
\hline Sarasbaug & $\begin{array}{l}\text { Used to be a lake, one of the biggest recreational parks in } \\
\text { Pune, well known for the Ganesh Temple on its premises, } \\
\text { constructed by Nanasaheb Peshwe (Sarasbaug.in, 2019) }\end{array}$ & 1750 \\
\hline Shinde Chhatri & $\begin{array}{l}\text { Temple dedicated to Mahadji Shinde, a commander in the } \\
\text { Maratha Army of the } 1700 \text { s (Unnithan, 2018) }\end{array}$ & 18th Century \\
\hline Dagdu Sheth Ganpati & $\begin{array}{l}\text { Located in the heart of the city and a focal point of } \\
\text { festivities, the temple is one of the biggest Hindu symbols in } \\
\text { Pune (Dagdushethganpati.com, 2015) }\end{array}$ & 1891 \\
\hline $\begin{array}{l}\text { Aga Khan Palace-Gandhi } \\
\text { memorial }\end{array}$ & $\begin{array}{l}\text { Gandhi and his wife Kasturba lived here for } 4 \text { years after the } \\
\text { Quit India movement and the Palace also houses the } \\
\text { Mahatma's samadhi. It throws light on Mahatma's life- the } \\
\text { Gandhi National Memorial Society (Museumsofindia.org, } \\
\text { 2019) }\end{array}$ & $\begin{array}{l}\text { Aga Khan Palace } \\
\text { in } 1892 \\
\text { Gandhi Museum } \\
\text { established in } \\
1974\end{array}$ \\
\hline National Defence Academy & Centre for defence training & 1954 \\
\hline Raja Dinkar Kelkar Museum & $\begin{array}{l}\text { Houses Kelkar's collection of artefacts that range from toys, } \\
\text { to kitchenware, to furniture and other objects that are of } \\
\text { historical significance and also has the famous Mastani } \\
\text { Mahal (Kelkar Museum, 2019) }\end{array}$ & 1962 \\
\hline Darshan Museum & $\begin{array}{l}\text { Museum dedicated to the life and teachings of Sadhu } \\
\text { Vaswani (a renowned saint, scholar and spiritual leader) }\end{array}$ & 2011 \\
\hline $\begin{array}{l}\text { Southern } \quad \text { Command } \\
\text { Museum }\end{array}$ & $\begin{array}{l}\text { The artefacts contained in the museum range from medals } \\
\text { and flags of the Southern Command Regiment of the Indian } \\
\text { Army, information about key battles and stories of gallantry } \\
\text { (Museumsofindia.org, 2019). }\end{array}$ & \\
\hline
\end{tabular}

Some of these museums and places of historical significance are vying for attention from the state and the larger public. Does this impressive assemblage of museums and heritage sites, part of a more comprehensive network of other history and identity-preserving sites feature prominently around the metro-routes? 
Figure 1 illustrates the metro development phase-wise of the city of Pune, while Figure 2 shows the distribution of the destinations included in Pune Darshan (local city bus tour) bus route. The map also indicates museums in the city which are not part of Pune Darshan. Visual interpretation of the map indicates that the majority of places included in Pune Darshan are located within old Pune city. This area houses most of the predominant Maharashtrian (or rather, Maratha) population of the city, who claim to be native to the area. This area is also termed as one of 'Pune's traditional neighbourhoods' or the peths and historically has also been the capital of the Maratha empire (Preston, 2002). Destinations chosen by the Pune Darshan bus range from Pataleshwar Caves, Shinde Chhatri, Darshan Museum, Kelkar Museum, Lal Mahal, Shaniwar Wada, Saras Bagh and Dagdusheth Temple. The only destinations not in old Pune that are covered by the Pune tour bus are Darshan Museum, War Memorial, Rajiv Gandhi Zoological Park and Aga Khan Palace. Museums and heritage sites considered as representing the cultural ethos of a city draw attention to further assessment of its inclusion in the development plans of Pune.

\section{Pune's Developmental Plans: Museums, Monuments and Metro Route}

Pune has been an educational and cultural centre of Maharashtra in India and its conversion into a smart city has led to several pertinent challenges with respect to inclusive development and growth. There are two broad approaches suggested by the participating cities for smart city projects: 1. Area Based Development (ABD) (Figure 1). This map depicts the metro development routes in 3 phases. Phase one is nearing completion and it intersects at the centre of the city which is also densely populated. The old Pune city is located around the intersection of the metro route and 2. Pancity projects. ABD projects include greenfield or brownfield projects. Greenfield projects include the development of new settlements with meticulous planning. Brownfield projects include improving certain streets to make them walkable or beautification/landscaping of urban water bodies. Pan-city projects include the development of parking lots, installation of CCTV cameras, and a central monitoring station.

In this area, a smart street project is already being implemented for improving walkability in a selected road segment. The other projects would be the development of hospitals and the Bus Rapid Transit system (BRT), to name a few. On the other hand, construction of Metro, Smart Street lighting, CCTV camera installation and a Digital Experience Centre are the Pan-city projects.

In total, there are 15 museums included in Pune Darshan. There are, however, 32 other museums and heritage sights. The blue dots depict the various monuments, heritage sites, and museums covered in the Pune sightseeing route (Figure 2). The red dots depict other museums not covered in Pune darshan (sightseeing) (Figure 2). These sites' spatial analysis revealed that metro route in phase I covers only three museums and a cluster of heritage sites. In phase two, only three tourist sites and four other museums are covered. While in the final phase covering the periphery of Pune and connects it to the core, only one museum falls in its route and does not cover any heritage sites from the Pune darshan route. This leaves the majority of the museums and sites out of the city development plans. This verifies the hypothesis of lack of integration of the cultural heritage sites into the metro route. 


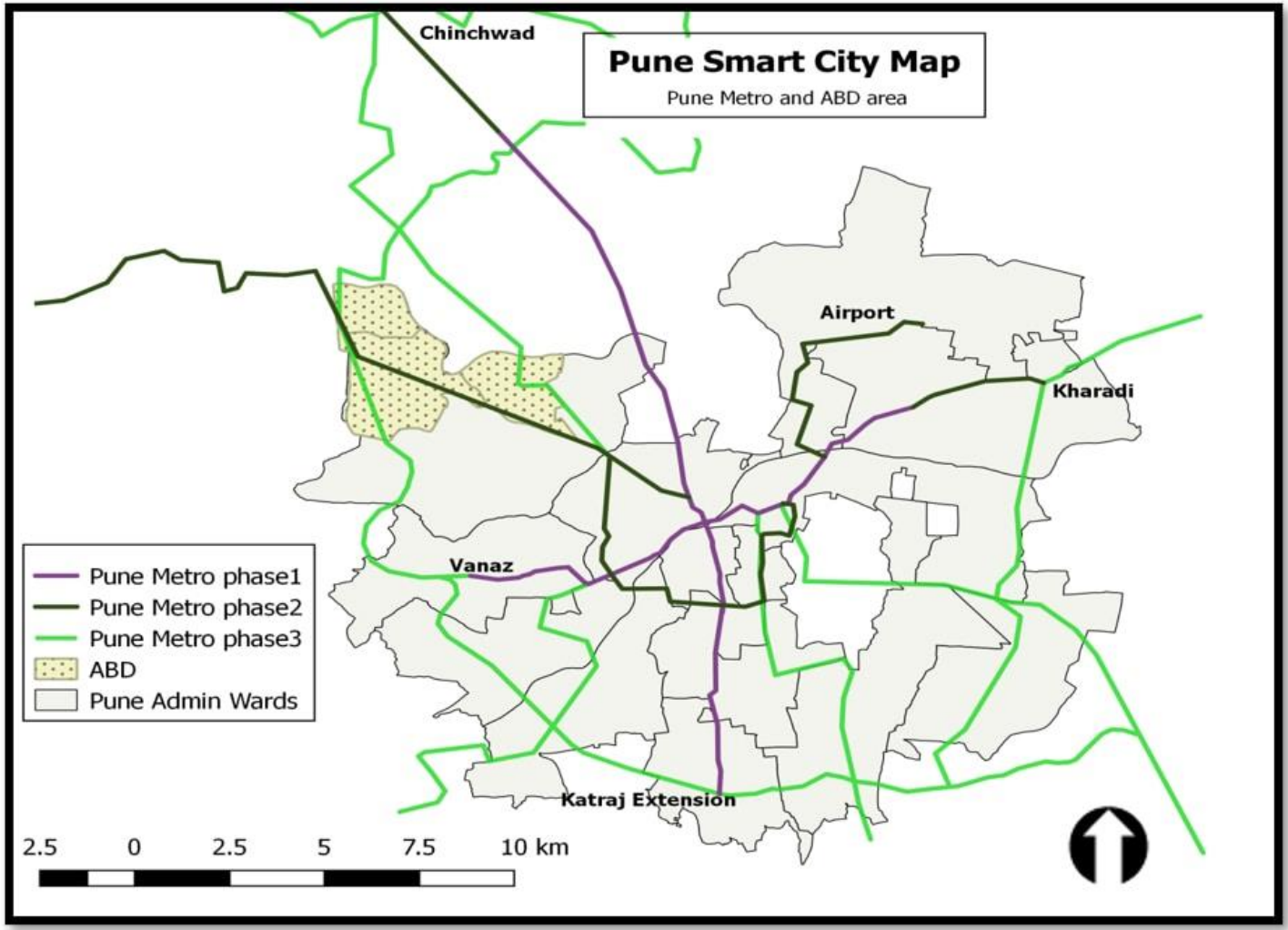

Figure 1: Depicts the Metro Development Phase-Wise Plan. ABD-Area Based Development Source: Authors Prepared the Map Using Ward Boundaries and Metro Lines Derived From Openly Available Data Post Verification with the Maps by the Municipal Corporation

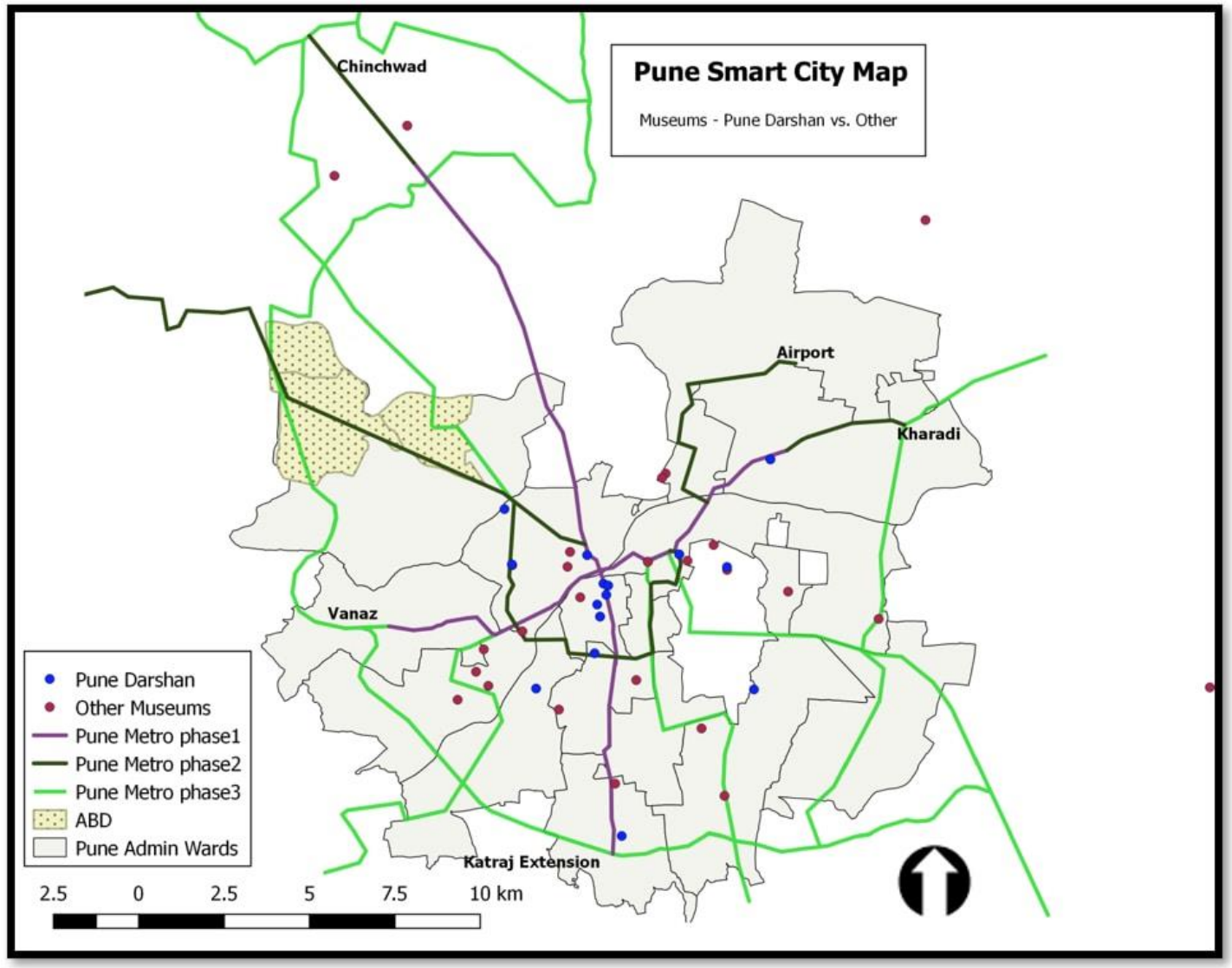

Figure 2: Museums and Monuments Covered and Not Covered Along the Metro Routes Source: Pune Darshan Locations were Geocoded by the Authors 


\section{Smart City Planning and Cultural Heritage}

According to the Greater London Authority:

Great cities are defined by their culture. They are defined by their history through their local heritage, museums and archives, historic buildings, festivals, food and local traditions. But a great city is also defined by its contemporary culture - its artists and arts venues, film and television, music and games, photography and crafts, fashion and design, and its buzzing informal offering from skate parks to restaurants, pubs and night clubs. (Yang et al., 2016: 161).

The question arises as to whether the powerful smart city paradigm and especially Pune's smart city development plan have considered the city's aforementioned understanding in its primarily techno-infrastructural project.

Heritage elements such as museums and monuments are increasingly being recognised as vital to standing up attractive cities, towns and villages. For example, Hong Kong's giant $\mathrm{M}+$ museum has been explicitly conceived as the core of its cultural district, and its giant LED screen is expected to beam art images across the harbour as an attempt to retain Hong Kong's attractiveness to tourists and migrants (n.a, HongKong Buzz, 2019). Beijing's people-centred heritage conservation initiatives have focused on maintaining "the social networks of heritage areas" as well as the cohesiveness of the local community as witnessed in the 'Yangmeizhu Hutong Area' conservation project (Yang et al., 2016: 134) insert page number for this quote).

Los Angeles is making attempts to revitalise its decaying urban centre through museumbuilding, wherein museums are being seen as indispensable elements at the centre of modern city life (Financial Times, 2020). Heritage elements can also be embedded in local economic strategies to make a village or town more desirable and 'consumable' as a place for tourists and migrants (Bounia, 2017; pp 29-40). The urban renewal, social networking, mutual learning and peace-building implications of this alignment have positive economic implications as being recognised by cities worldwide (Yang et al., 2016). Museums and monuments have the potential to act as key enabling institutions to assist cities in realising the greater project of being more inclusive of their diverse populations by promoting learning and understanding across the traditionally divisive axes of class, caste, religion and culture. Smart city planners can harness this peace-making potential of museums and monuments by making adjustments to their current plans that focus on technology, hard infrastructure and economic growth to ensure more holistic development of cities.

\section{Museums, Urban Culture and Sustainability}

The concept of sustainable development has come to mean development that meets the needs of the present generation without compromising future generations' ability. It has been understood in terms of three key prongs; economic development, social welfare and environmental conservation. Incorporating museums and monuments into smart city planning enhance sustainability by improving both its economic and social welfare component (Pop \& Borza, 2014). Properly maintained museums and carefully planned transportation corridors and other smartification measures can lay the foundations for a heritage economy that can generate jobs with a very low emissions footprint compared to more intensive sectors such as manufacturing (Nasser, 2003). Given their constant need for upkeep and high maintenance threshold, museums can also provide jobs at all levels. Given Pune's large IT industry, its museums also constitute significant digital solutions opportunities that can upgrade museums and make them more accessible to the public. This could potentially increase the size of Pune low-emissions IT sector further, reducing the pressures for job creation through the more emissions-intensive automobile sector. Advanced economies such as the US have large service sectors, and Pune's smart city planning should also aim to achieve sustainability by leveraging its existing IT strengths to boost its museum ecosystem. 


\section{Conclusion}

The idea of a smart city originated in the Indian context as a solution to solve a particular problem: improving the techno-infrastructural capacity of already overburdened Indian cities to better handle India's rapid and chaotic urbanisation and to make cities the engines of India's economic growth. Deeper penetration of technology and a massive build-up of infrastructure are two prongs of a strategy that are thought to make it easier for cities to retain residents, attract investment, and accommodate intra and inter-state immigrants. More specifically, enabling walkability, large-scale mass-transit, prime-land access to revenuegenerating malls and businesses, affordable access to high-speed internet and enhanced state surveillance measures via CCTV cameras have been conceived as initiatives to upgrade India's cities.

Clearly, this massive upgradation and modernisation of Indian cities, including Pune, has its advantages. Citizens may find it easier to travel due to greater mass transit availability, health outcomes improve as people walk more to nearby places and more excellent CCTV camera monitoring at public places could act as a deterrent for traffic violators and criminals.

However, this quest to 'modernise' Pune's software through Area-based and pan-city technological solutions and 'upgrade' it's hardware through substantial investments in physical infrastructure has not reckoned with the vital role played by institutions such as museums and heritage sites in creating, maintaining and fostering the 'social infrastructure' of the city. This social infrastructure depends crucially on the preservation of inclusive histories of the unique experiences of minorities such as Native Americans or African Americans (Washington DC area) that would otherwise be rendered invisible and embody acts of remembrance and reconciliation. Such acts are indispensable to assist minorities in identifying with the city and creating a cosmopolitan culture of inclusivity which is more likely to attract blue-chip corporations and high-skilled workers.
Pune should not just be planned to stimulate economic growth, as the current smart city plan does, but also to ensure that institutions such as museums that instil a culture of curiosity, learning and pride in history should be incorporated into key infrastructural and technological up-gradation plans. This will result in a rebalancing of currently skewed technodeterministic plans to more culturally and socially inclusive ones, creating economically productive, environmentally sustainable and socially inclusive Pune.

The Government plans to replicate the smart city paradigm in 100 Indian cities. Pune's example shows that, without careful and inclusive planning, a full roll-out of the smart city project will exclude a large number of historical and cultural spaces such as museums and heritage sites from emerging as an integral part of smart cities across the country and render them peripheral to modern urban life. This could reduce footfall at already struggling museums and force them to allocate increasing fractions of their meagre budgets for community outreach and advertising rather than for artefact preservation.

Urban planners should look at museums and heritage sites to be incorporated as an important element in their smart city plans as part of a heritage ecosystem. The 'shape' of the emerging physical and digital infrastructure of a smart city should ensure that the heritage ecosystem is not marginalised from the emerging urban landscape purely by economic and popular cultural institutions. The economic revitalisation of the city via smart city initiatives should go hand-in-hand with its social and cultural revitalisation through carefully designed plans that funnel more footfalls towards the city's heritage ecosystem, maximising its revenue, knowledge-transfer and peacebuilding implications. Current smart city plans lack this composite and holistic understanding of the heritage ecosystem's role in creating functional cities. 


\section{References}

Allam, Z., \& Newman, P. (2018). Redefining the smart city: Culture, metabolism and governance. Smart Cities, 1(1), pp.4-25

Anand, A., Sreevatsan, A., Taraporevala, P. (2018). An overview of the smart cities mission in India. Policy Brief. French National Research Institute for Sustainable Development and Centre for Policy Research. pp.1-4. https://cprindia.org/system/tdf/policy-briefs/ Ashcroft, Bill (2017). Postcolonial theory. The Wiley-Blackwell Encyclopedia of Social Theory. https://doi.org/10.1002/9781118430873.est02 81

British Broadcasting Corporation (2019). Louvre draws record $10 m$ visitors. British Broadcasting Corporation.

https://www.bbc.com/news/world-europe46748282

Bounia, Alexandra (2017). Cultural societies and local community museums: A case study of a participant museum in Greece; Cultural Heritage, Cultural Policy. pp. 29-40. www.ejournals.ed/zarzad zanie-w-kulturze)

Caragliu, A., Del Bo, C., \& Nijkamp, P. (2011). Smart cities in Europe. Journal of Urban Technology, 18(2), 65-82.

Census of India (2011). Government of India., www.censusindia.gov.in

Dafoe, Allan (2015). On Technological determinism: A typology, scope conditions and a Mechanism. Science, Technology, and Human Values. 40(6)

https://doi.org/10.1177/0162243915579283

Dagdushethganpati (2015).

http://www.dagdushethganpati.com/abouttemple/

Datameet (2019).

https://github.com/datameet-pune/datameetPune.github.io/tree/master/maps

Datta, A. (2015). New urban utopias of postcolonial India. Dialogues in Human Geography. 5(1), pp. 3-22.

doi:10.1177/2043820614565748
Datta, A. (2018). The digital turn in postcolonial urbanism: Smart citizenship in the making of India's 100 smart cities. Transactions of the Institute of British Geographers, 43(3), pp.405419.

Diddee, J., Gupta, S., \& Bhandare, S. (2000). Pune: Queen of the Deccan. Elephant Design Pvt. Limited.

Financial Times (2020). Cities turn to high culture to help them work better. https://www.ft.com/content/55bf2972-473011e5-af2f-4d6e0e5eda22

Hall, R. E., Bowerman, B., Braverman, J., Taylor, J., Todosow, H., \& Von Wimmersperg, U. (2000). The vision of a smart city (No. BNL-67902; 04042). Brookhaven National Lab., Upton, NY (US).

Han, H., \& Hawken, S. (2018). Introduction: Innovation and identity in next-generation smart cities. City, Culture and Society. 12, pp.14.

HongKong Buzz (2019). Giant LED screen to beam moving art images across harbour from Cultural District's M+ Building (2019). HongKong Buzz.

https://hongkongbuzz.hk/2019/12/giant-ledscreen-to-beam-moving-art-images-acrossharbour-from-cultural-districts-m-building Katz, B. (2017). This museum was the world's most-visited in 2016. Smithsonian Magazine. https://www.smithsonianmag.com/smartnews/museum-was-worlds-most-visited-2016180963624/

Kelkar Museum (2019).

https://rajakelkarmuseum.org/about.html

Metropolitan Area Transit Authority (WMATA) (2019).https://www.wmata.com/schedules/ma ps/upload/2019-System-Map.pdf

Mundhe, N.N., \& Jaybhaye, R.G. (2017). Chronological development of Pune from 7582014 AD International Journals of Environment, Ecology, Family and Urban Studies. 7(5)

Museums of India (2019). An online resource for mapping the museums of India. Museums of India. https://www.museumsofindia.org/ 
Nasser, N. (2003). Planning for urban heritage places: reconciling conservation, tourism, and sustainable development. Journal of Planning Literature, 17(4), pp. 467-479. https://doi.org/10.1177\%2F0885412203017004 001

PMC Open Data Store (2020). Pune Municipal Corporation.

http://opendata.punecorporation.org/Citizen/U ser

Pop, I. L., \& Borza, A. (2014). Increasing the sustainability of museums through international strategy. Economia Seria Management 17, pp. 248-264.

Preston, L. W. (2002). Shrines and neighbourhood in early nineteenth-century Pune, India. Journal of Historical

Geography, 28(2), pp. 203-215.

10.1006/jhge.2001.0398

Pune Municipal Corporation (2019).

https/www.pmc.gov.in, 2019

Pune Smart City Pune (2019). Smart city wins two smart project awards - Pune smart city portal. https://punesmartcity.in/pune-smartcity-wins-two-smart-project-awards/

Sarasbaug (2019). http://sarasbaug.in/

Smart Cities Mission (2016). Smart cities mission. Government of India.

http://smartcities.gov.in/

Smart city proposal (2019). Pune Municipal Corporation. http://pmc.gov.in/en/smart-cityproposal

Smith, R. M., Pathak, P. A., \& Agrawal, G. (2019). India's "smart" cities mission: A preliminary examination into India's newest urban development policy. Journal of Urban Affairs, 41(4), pp. 518-534

Smithsonian Institute (2019). Our museums, galleries and zoo. https://www.si.edu/museums Sonkoly, Gabor (2017). Historical urban landscape. Springer International $P U$ Sonne, Lina (2018). Mumbai metropolitan region: Putting the art in SmArt; urban futures. Observer Research Foundation. https://www.orfonline.org/expertspeak/mumbai-metropolitan-region-puttingthe-art-in-smart-46000/

The World Bank (2018). Urban population. https://data.worldbank.org/indicator/SP.URB.T OTL.IN.ZS

Townsend, A. (2013). Smart cities: Big Data, civic hackers, and the quest for a new utopia. New York: W.W. Norton \&Co.

Unnithan, V. (2018, November 8). Under the Canopy. Pune Mirror.

https://punemirror.indiatimes.com/entertainm ent/unwind/under-thecanopy/articleshow/66541324.cms

Vogeler, I. (2010). Critical Cultural Landscapes of North America. Chapter1.

http:// people.uwec.edu/ivogeler/CCLbookchapters-pdf/index.htm.

What is smart City? Government of India, Smart cities mission

http://smartcities.gov.in/content/innerpage/wh at-is-smart-city.php

Williams, A., Robles, E., \& Dourish, P. (2009). Urbane-ing the City: Examining and refining the assumptions behind urban informatics. The Handbook of Research on Urban Informatics: The Practice and Promise of the Real-Time City. Doi 10.4018/978-1-60566-152-0.ch001

Yang, Bing, Perlman, \& Janice (2016). Humanising cities Through Culture. Culture, Urban, Future. Global report. pp. 131-161. https://unesdoc.unesco.org/ark:/48223/pf0000 260634

Ziyaee, M. (2018). Assessment of urban identity through a matrix of cultural landscapes. Cities, 74. https://doi.org/10.1016/j.cities.2017.10.021

\section{Conflict of Interest Statement}

The authors declare that there is no conflict of interest.

\section{Acknowledgements}

We would like to acknowledge FLAME university for research fund for the project 'Smart city and Cultural Heritage'. We also, thank the anonymous reviewers for reviewing 
the paper and giving feedback that helped revise the paper.

\section{About the Authors}

Poonam Gandhi has a doctoral degree in Sociology and is currently an Associate Professor at FLAME University. Her research interests are in the fields of Sociology of Art and Culture, Social Gerontology, Gender, Family and Urban Studies. She has authored a book on Sociology of Art and has to her credit several research papers published in peer-reviewed national and international journals as well as chapters in edited books.

Chaitanya Ravi's research interests lie at the intersection of energy policy, environmental policy, international relations and South Asia. His PhD dissertation at George Mason University, USA was a technological history of the debate over the US-India nuclear cooperation agreement in India. A revised version of his dissertation was recently published as a book (A Debate to Remember-The US-India Nuclear Deal) by the Oxford University Press-India.

Prasad Pathak is a geographer interested in urban issues including urban growth, urban mobility, environmental issues and urban sociocultural landscape. He has a Ph.D. degree from
University of North Carolina at Greensboro, North Carolina, USA. He is currently the Chair for FLAME Centre for Earth and Environment at FALEM University. He has authored multiple peer-reviewed scientific papers and contributed to certain chapters regarding GIS and Smart City Mission of India.

Smriti Jalihal has a Bachelors degree in Environmental Studies and Public Policy and is currently completing her Post Graduate Diploma in Interdisciplinary Studies and Research at FLAME University, Pune. Her research interests include the intersections of environmental policy, urban studies and social policy.

\section{Author Contribution Statement}

Poonam Gandhi: conceptualisation, secondary data, developing the draft, developing the final draft, editing and reviewing.

Chaitanya Ravi: conceptualisation, secondary data, developing the draft, editing and reviewing

Prasad Pathak: conceptualisation, secondary data, developing the draft, visualisation of data, maps

Smriti Jalihal: secondary data, historical data 